\title{
Rasisme dan Penerapan Pasal Makar terhadap Kebebasan Ekspresi Politik Papua
}

\author{
Herlambang P. Wiratraman \\ Fakultas Hukum Universitas Airlangga \\ herlambang@fh.unair.ac.id
}

\section{Abstract}

Freedom of political expression has not been fully guaranteed in the Indonesian legal system. One of the most prominent in the legal debate is the matter of treason (makar) charges against political expressions of self-determination. In the case of Papua, many Papuans have been detained, criminalised, and even killed because of their political expression. Interestingly, the Constitutional Court, through its decision Number 7/PUU-XV/2017, provided guidance in its 'ratio decidendi' argument, specifically the interpretation of treason phrases in the Criminal Code. Interpretation is given by the Constitutional Court after seeing the reality that law enforcement has been arbitrarily abused by the application of the treason article. This is contrary to the freedom of association, opinion and expression, as guaranteed in the 1945 Constitution of the Republic of Indonesia. This article discusses how the application of the phrase treason in law enforcement, especially in connection with the conviction of many Papuans after the Surabaya anti-racism rallies in September 2019. A number of district court decisions on dozens of convicted Papuans show that the legal system that guarantees freedom of political expression has not changed much and law enforcement in fact emphasises the position of racial discrimination and is far below the standard of human rights law.

Keywords: treason; political expression; freedom of expression; the decision of the Constitutional Court. 


\section{Abstrak}

Kebebasan ekspresi politik belum sepenuhnya dijamin dalam sistem hukum Indonesia. Salah satu yang paling mengemuka dalam perdebatan hukum adalah soal tuduhan makar terhadap ekspresi politik menentukan nasib sendiri. Dalam kasus Papua, tidak sedikit jumlah warga Papua yang ditahan, dikriminalkan, hingga tewas terbunuh karena soal ekspresi politiknya. Menariknya, Mahkamah Konstitusi melalui putusannya Nomor 7/PUU$\mathrm{XV} / 2017$ memberikan panduan dalam argumen ratio decidendinya, khusus interpretasi frasa makar dalam Kitab-Undang-Undang Hukum Pidana. Penafsiran diberikan oleh Mahkamah Konstitusi setelah melihat realitas penegakan hukum telah banyak disalahgunakan penerapan pasal makar. Hal demikian bertentangan dengan kebebasan berkumpul, berpendapat dan berekspresi, sebagaimana dijamin dalam Undang-Undang Dasar Negara Republik Indonesia Tahun 1945. Artikel ini membahas bagaimana penerapan frasa makar dalam penegakan hukumnya, khususnya berkaitan dengan dipidananya banyak warga Papua setelah aksi anti rasisme Surabaya pada September 2019. Sejumlah putusan pengadilan negeri atas puluhan warga Papua yang dipidana tersebut memperlihatkan sistem hukum yang menjamin kebebasan ekspresi politik tidak banyak berubah dan penegakan hukum justru menegaskan posisi diskriminasi rasial serta jauh dari standar hukum hak asasi manusia.

Kata kunci: makar; ekspresi politik; kebebasan ekspresi; putusan Mahkamah Konstitusi.

\section{A. Pendahuluan}

"Aksi di Papua dan oleh orang Papua, apa pun isunya, akan dituduh makar, padahal aksi dari kelompok lain ya aksi saja... Watak rasis tersebut membuat aparat terbiasa mencari-cara kesalahan yang sebenarnya tak pernah ada."1

Artikel ini membahas kecenderungan diskriminasi dalam penegakan

1 Kalimat di atas disampaikan oleh Asfinawati, direktur Yayasan Lembaga Bantuan Hukum Indonesia (YLBHI). Kantor di bawahnya, Lembaga Bantuan Hukum (LBH) Jayapura, selama ini aktif memberikan pembelaan hukum di pengadilan atas kasus-kasus makar. Tirto.id, "Timpangnya Putusan Hukum Pelaku dan Pemrotes Rasisme ke Orang Papua”, https: / / tirto.id/ timpangnya-putusan-hukum-pelaku-dan-pemrotes-rasisme-keorang-papua-fF6j, 9/6/2020, diakses 15/2/2021. 
hukum melalui studi kasus makar yang ditujukan pada warga Papua dan penerapan hukum pidana makar dari sudut politik hukum dan hak asasi manusia. Tiga persoalan yang hendak didiskusikan adalah: bagaimana penerapan frasa makar dalam penegakan hukumnya, bagaimana standar hukum kebebasan ekspresi politik dikaitkan dengan pasal makar, dan apa bentuk pelanggaran hukum dalam proses penegakan hukum ketika negara terus menegaskan posisi diskriminasi rasial serta jauh dari standar hukum hak asasi manusia (HAM).

Kecenderungan diskriminasi dalam penegakan hukum terkait ekspresi politik Papua bisa dilihat misalnya dalam kasus berikut ini. Bermula di Jalan Kalasan Surabaya, persisnya di Asrama Papua yang selama ini menjadi tempat mahasiswa Papua menimba ilmu pendidikan tinggi di berbagai kampus. Setelah mengalami sejumlah aksi pengepungan dan rasialisme di bulan Agustus 2019, teror terhadap penghuni asrama terjadi lagi pada 9 September 2019 pagi. Mahasiswa dalam asrama dikejutkan aksi pelemparan sejumlah ular ke dalam asrama. "Pagi tadi saat masih gelap, ada empat orang berpakaian preman berhenti di depan asrama, mereka masukkan ular, ada tiga ekor itu di dalam karung terbuka," kata salah satu penghuni asrama, Yoab Orlando, kepada CNNIndonesia.com. ${ }^{2}$

Peristiwa yang terjadi di asrama mahasiswa Papua di Surabaya sebenarnya hanya salah satu dari begitu banyak kasus serangan terhadap mahasiswa atau warga Papua yang terjadi di berbagai kota di Indonesia. Namun, yang menjadi besar dampaknya adalah siklus aksi rasisme yang berulang. Aksi rasisme yang diperlihatkan secara terbuka dengan menyebut 'monyet', pula pelemparan ular, akibatkan kasus tersebut membesar dan membentuk solidaritas sosial yang besar di berbagai wilayah Indonesia, tak terkecuali di Papua. Aksi rasisme ini terjadi setelah ada kabar para penghuni asrama yang dituduh merusak bendera merah putih. Para mahasiswa sempat dibawa ke

2 CNNIndonesia.com, "Asrama Papua di Surabaya Dilempari Karung Berisi Ular Piton”, https://www.cnnindonesia.com/nasional/2019090910273920-428670/ asrama-papua-di-surabaya-dilempari-karung-berisi-ular-piton, 9/9/2019, diakses $15 / 2 / 2021$. 
kantor polisi, tapi dilepaskan karena tuduhan tak terbukti.

Ekses rasisme begitu besar karena melahirkan protes massal. Di Jayapura, Manokwari dan Sorong, lautan manusia berdemo jalan kaki dan tumpah ruang dijalanan. Gedung parlemen daerah di Manokwari dibakar. Fasilitas publik di Sorong seperti bandara dirusak, pula mobil-mobil di lahan parkir bandara itu dirusak. Gubernur Papua, Lukas Enembe, menyatakan terbuka, "kami bukan bangsa monyet, kami manusia."3

Fakta demikian direspons oleh aparat kepolisian dengan menangkapi mahasiswa dan warga Papua di berbagai wilayah, dan mereka ditahan dengan tuduhan makar. Misalnya, diberitakan sebanyak 20 orang yang telah ditetapkan tersangka, enam di antaranya yang berinisial: KA, WW, AI, AS, SS, PM dikenakan undang-undang darurat terkait kepemilikan senjata tajam dan juga melakukan kegiatan makar Pasal 106 dan Pasal 110 ayat (2) angka 1 Kitab Undangundang Hukum Pidana (KUHP). Pasal 106 KUHP menyatakan, "Makar dengan maksud supaya seluruh atau Sebagian dari wilayah negara diancam dengan pidana penjara seumur hidup atau pidana penjara sementara palinglama dua puluh tahun”. Sedangkan Pasal 110 ayat (2) angka 1 KUHP, menyatakan, "Pidana yang sama diterapkan terhadap orang-orang yang dengan maksud berdasarkan pasal 104, 106, dan 108, mempersiapkan atau memperlancar kejahatan: 1. Berusaha menggerakkan orang lain untuk melakukan, menyuruh melakukan atau turut serta melakukan agar memberi bantuan pada waktu melakukan atau memberi kesempatan, sarana atau keterangan untuk melakukan kejahatan."

Polisi mengamankan barang bukti berupa beberapa stel pakaian loreng dengan lambang bendera bintang kejora, berbagai macam senjata tajam dan kartu anggota TPNPB serta dokumen terkait west Papua. Setelah itu, terjadi kembali gelombang penahanan atas 13 orang berinisial SK, MI, MS, LI, SJ, RT, CHB, YW, YT, IB, YB, NM, MY, yang dikenakan pasal makar, Pasal 106 KUHP, serta satu orang

3 Tirto.id, "Siklus Rasisme terhadap Mahasiswa Papua", https://tirto. id/siklus-rasisme-terhadap-mahasiswa-papua-egA4, 20/8/2019, diakses $16 / 2 / 2021$. 
tersangka berinisial LK, yang tak hanya dituduh makar, namun juga penghasutan, sebagaimana Pasal 160 KUHP. Ancaman hukuman bagi mereka semuanya maksimal 20 tahun penjara. ${ }^{4}$

Penggunaan pasal makar kembali mengingatkan pada Putusan Mahkamah Konstitusi Nomor 7/PUU-XV/2017, yang memberikan panduan dalam argumen ratio decidendi-nya, dalam menafsir frasa makar, khususnya dalam KUHP. Penafsiran diberikan oleh Majelis Hakim Mahkamah Konstitusi setelah melihat realitas penegakan hukum telah banyak disalahgunakan penerapan atas pasal makar. Faktanya, mengapa penahanan dan pemenjaraan terhadap mereka begitu mudahnya dikenakan pasal makar? Mengapa pula peristiwa demikian begitu mudah terjadi dan berulang-ulang? Pendekatan etnografi dalam memahami konflik dan upaya gerakan di Papua, memang menjadi tak mudah dan selalu membutuhkan negosiasi interdependensi yang kompleks. ${ }^{5}$

Gelombang kriminalisasi yang cenderung menopang diskriminasi rasial jelas bertentangan dengan kebebasan berkumpul, berpendapat dan berekspresi, sebagaimana dijamin dalam Undang-Undang Dasar Negara Republik Indonesia Tahun 1945. Sayangnya ini terus terjadi di masa Presiden Joko Widodo (Jokowi) dan memperlihatkan tren kemunduran demokrasi. ${ }^{6}$ Dalam studi peta jalan, disebutkan sumber konflik Papua dikelompokkan menjadi empat masalah, salah satunya dampak marjinalisasi dan diskriminatif terhadap ekonomi masyarakat adat Papua. ${ }^{7}$

4 CNNIndonesia.com, "Polisi Tetapkan 20 Tersangka Kasus Makar di Papua”, https: / / www.cnnindonesia.com/nasional/20191202205913-12-453521/ polisi-tetapkan-20-tersangka-kasus-makar-di-papua, 2/12/2019, diakses $16 / 2 / 2021$.

5 Eben Kirksey, Freedom in Entangled Worlds: West Papua and the Architecture of Global Power (Durham London: Duke University Press, 2012); Noelani Goodyear-Ka'ōpua dan April K. Henderson, Morning Star Rising: The Politics of Decolonization in West Papua (University of Hawaii Press, 2021).

6 Wijayanto, dkk., Nestapa Demokrasi di Masa Pandemi: Refleksi 2020, Outlook 2021 (Jakarta: LP3ES, 2021).

7 Muridan Satrio Widjojo, Adriana Elisabeth, dan Amirudin Al Rahab, Papua Road Map: Negotiating the Past, Improving the Present, and Securing the Future (Jakarta: LIPI, 2010). 
Analisis dalam artikel ini melengkapi kajian peradilan makar dalam kasus Papua sebagaimana pernah dituliskan Gunawan, dkk. (2005), ${ }^{8}$ studi doktrinal seperti ditulis Wulandari dan Moeliono (2017), ${ }^{9}$ atau mengkritisi sejumlah studi yang begitu menyederhanakan masalah soal sekadar terpenuhinya unsur-unsur pasal pemidanaan, sebagaimana ditulis Panjaitan, dkk. (2010). ${ }^{10}$ Dalam membahasnya, artikel ini memulai dengan ulasan perdebatan konstitusionalisme kebebasan ekspresi, termasuk ekspresi politik di dalamnya. Bagian berikutnya membahas makar dalam putusan Mahkamah Konstitusi Nomor 7/PUU-XV/2017 dan bagaimana doktrin hukumnya. Pada bagian akhir, akan dikemukakan temuan-temuan dalam studi ini.

\section{B. Hukum Kebebasan Ekspresi}

Muhammad Hatta dalam rapat besar Sidang Kedua Badan Penyelidik Usaha Persiapan Kemerdekaan Indonesia (BPUPKI), 15 Juli 1945, menyatakan, “... janganlah kita memberikan kekuasaan yang tidak terbatas kepada negara untuk menjadikan di atas negara baru itu suatu negara kekuasaan. Sebab itu ada baiknya dalam salah satu fasal, misalnya fasal yang mengenai warga negara jangan takut mengeluarkan suaranya.” Karena konstitusi (grondrechten), kedudukannya paling dasar dan tertinggi hierarkinya dalam peraturan perundang-undangan di Indonesia, maka pijakan konstitusi menjadi penting.

Kebebasan berekspresi sesungguhnya telah diatur rumusannya dalam Konstitusi, yakni Pasal 28 Undang-Undang Dasar 1945, "Kemerdekaanuntukberserikat dan berkumpul, untukmengeluarkan

8 Gunawan, dkk., Papua on Trial: uraian penjelasan Perhimpunan Bantuan Hukum dan Hak Asasi Manusia Indonesia atas pengadilan HAM perkara Abepura dan pelanggaran HAM di Papua (Jakarta: Perhimpunan Bantuan Hukum dan Hak Asasi Manusia Indonesia, 2005).

9 Widati Wulandari dan Tristam P. Moeliono, "Problematika Pengertian Aanslaag-Aanslaag tot en Feit: Perbandingan Makar dalam KUHP, WvSNI dan SR”, Padjadjaran Jurnal Ilmu Hukum, 4, 3 (2017): 473-92.

10 Lani Sujiagnes Panjaitan, dkk., "Penerapan Hukum Pidana terhadap Tindak Pidana Makar oleh Organisasi Papua Merdeka (OPM) di Kabupaten Jayawijaya (Studi Putusan Nomor 38/Pid.B/2011/PN.Wmn)”, USU Law Journal, 4, 3 (2016): 88-98. 
pikiran dengan lisan dan tulisan dan sebagainya ditetapkan dengan undang-undang". Kebebasan dasarini merupakan salah satu ketentuan hak asasi manusia tertua sejak Indonesia merdeka. Sehari setelah proklamasi, pada Sidang Panitia Persiapan Kemerdekaan Indonesia (PPKI), 18 Agustus 1945, rumusan Pasal 28 Undang-Undang Dasar yang dihasilkan dalam Sidang BPUPKI tersebut dibacakan kembali oleh Ketua Sidang PPKI, Ir. Soekarno, dan akhirnya disahkan. Rumusan pasal inilah yang tetap utuh dipertahankan hingga amandemen Undang-Undang Dasar 1945 tahun 1999-2002, yakni Pasal 28 Undang-Undang Dasar Negara Republik Indonesia Tahun 1945.

Berdasarkan apa yang telah digagas dan diperdebatkan mengenai kebebasan berekspresi, baik dalam sidang BPUPKI maupun penetapannya dalam sidang PPKI, menunjukkan garis yang sama bahwa kebebasan tersebut ditujukan untuk menentang kesewenangwenangan kekuasaan (detournement de pouvoir atau abuse of power) dan sekaligus agar pemerintah lebih bisa mempertanggungjawabkan kebijakannya (state responsibility). ${ }^{11}$ Sekalipun dalam persidangan pembentukan konstitusi alami perbedaan, perumus sama-sama meyakini konsep kebebasan dasar berekspresi sangatlah penting ditempatkan dalam posisi pertanggungjawaban negara, utamanya menjamin hak-hak asasi manusia. Keberhasilan memasukkan gagasan kebebasan berpendapat dan berekspresi melalui pasal-pasal di dalam UUD 1945 merupakan kemajuan dalam membangun pondasi hukum bernegara untuk memperkuat kontrak penguasarakyat dalam semangat konstitusionalisme Indonesia. ${ }^{12}$ Setelah melalui amandemen, UUDNRI 1945 mengatur setidaknya lima pasal yang terkait dengan kebebasan ekspresi, yakni Pasal $28^{13}, 28 \mathrm{C}$ ayat

11 Herlambang P. Wiratraman, "Kebebasan Berekspresi: Penelusuran Pemikiran dalam Konsitusi Indonesia,” Jurnal Konstitusi, 6, 1 (2009), hlm. 113.

12 Herlambang P. Wiratraman, "Hak-Hak Konstitusional Warga Negara Setelah Amandemen UUD 1945: Konsep, Pengaturan dan Dinamika Implementasi,” Jurnal Hukum Panta Rei, 1, 1 (2007).

13 "Kemerdekaan berserikat dan berkumpul, mengeluarkan pikiran dengan lisan dan tulisan dan sebagainya ditetapkan dengan Undang-undang." 
$(2)^{14}, 28 \mathrm{E}$ ayat $(3)^{15}, 28 \mathrm{~F}^{16}$ dan $28 \mathrm{G}$ ayat $(1)^{17}$.

Ketentuan hukum dasar demikian, pula diperkuat oleh ketentuan hukum nasional maupun hukum internasional, termasuk yang telah diratifikasi menjadi sistem hukum nasional. Ada dua perundangundangan terkait soal jaminan kebebasan ekspresi. Pertama, UndangUndang Nomor 9 Tahun 1998 tentang Kemerdekaan Menyampaikan Pendapat di Muka Umum, yang pada pokoknya mengatur mengenai tatacaramenyampaikan pendapatdimukaumumyangdiperbolehkan. Kedua, Undang-Undang Nomor 39 Tahun 1999 tentang Hak Asasi Manusia (UU HAM), yang pula mengatur sejumlah pasal tentang kebebasan ekspresi. Sebagai contoh, dalam Pasal 23 dan Pasal 25 UU $\mathrm{HAM}^{18}$, memiliki tiga substansi berbeda, soal hak pilih dalam politik, hak berpendapat dan berekspresi, serta hak mogok.

Lebih mendasar dan pula telah menjadi hukum Indonesia, adalah ratifikasi International Covenant on Civil and Political Rights, ICCPR 1966, ke dalam Undang-Undang Nomor 12 Tahun 2005. Pasal 19 ICCPR mengatur tentang kebebasan berpendapat dan berekspresi,

(1) Setiap orang berhak untuk berpendapat tanpa campur tangan;

14 "Setiap orang berhak untuk memajukan dirinya dalam memperjuangkan haknya secara kolektif untuk membangun masyarakat, bangsa, dan negaranya."

15 "Setiap orang berhak atas kebebasan berserikat, berkumpul, dan mengeluarkan pendapat."

16 "Setiap orang berhak untuk berkomunikasi dan memperoleh informasi untuk mengembangkan pribadi dan lingkungan sosialnya, serta berhak untuk mencari, memperoleh, memiliki, menyimpan, mengolah, dan menyampaikan informasi dengan menggunakan segala jenis saluran yang tersedia."

17 "Setiap orang berhak atas perlindungan diri pribadi, keluarga, kehormatan, martabat, dan harta benda yang dibawah kekuasaannya, serta berhak atas rasa aman dan perlindungan dari ancaman ketakutan untuk berbuat atau tidak berbuat sesuatu yang merupakan hak asasi."

18 Pasal 23: (1) "Setiap orang bebas untuk memilih dan mempunyai keyakinan politiknya; (2) Setiap orang bebas untuk mempunyai, mengeluarkan dan menyebarluaskan pendapat sesuai hati nuraninya, secara lisan dan atau tulisan melalui media cetak maupun elektronik dengan memperhatikan nilai-nilai agama, kesusilaan, ketertiban, kepentingan umum, dan keutuhan bangsa." Pasal 25: "Setiap orang berhak untuk menyampaikan pendapat di muka umum, termasuk hak untuk mogok sesuai dengan ketentuan peraturan perundang-undangan.” 
(2) Setiap orang berhak atas kebebasan untuk menyatakan pendapat; hak ini termasuk kebebasan untuk mencari, menerima dan memberikan informasi dan pemikiran apapun, terlepas dari pembatasanpembatasan secara lisan, tertulis, atau dalam bentuk cetakan, karya seni atau melalui media lain sesuai dengan pilihannya;

(3) Pelaksanaan hak-hak yang diicantumkan dalam ayat (2) pasal ini menimbulkan kewajiban dan tanggung jawab khusus. Oleh karenanya dapat dikenai pembatasan tertentu, tetapi hal ini hanya dapat dilakukan seesuai dengan hukum dan sepanjang diperlukan untuk: a) Menghormati hak atau nama baik orang lain; b) Melindungi keamanan nasional atau ketertiban umum atau kesehatan atau moral umum.

Pasal 19 ICCPR ini menjadi pintu masuk berkembangnya doktrin kebebasan berpendapat dan berekspresi, termasuk bagaimana standar hukum untuk membatasi kebebasan tersebut. Hal ini karena kebebasan ekspresi, termasuk ekspresi politik, merupakan kebebasan yang bisa dibatasi (derogable rights). Konstruksi pasal 19 ICCPR ini sesungguhnya mempertegas Pasal 19 Deklarasi Universal Hak Asasi Manusia, DUHAM, yang dinyatakan pada $1948 .{ }^{19}$

\section{Kebebasan Ekspresi Politik}

Ekspresi politik merupakan bagian dari kebebasan ekspresi. Dalam teori kerap dibedakan antara ekspresi yang sifatnya politik dengan ekspresi seni, ataupun ekspresi yang sifatnya komersial. Namun, pembedaan itu menjadi tak relevan, ketika ekspresi seni pun memiliki substansi yang mengkritisi sistem politik, politisi atau mereka yang memiliki wewenang kekuasaan. Ekspresi politik dapat mengambil bentuk langsung melalui pernyataan lisan atau tulisan, maupun tidak langsung di antaranya melalui simbol, seni, gerak tubuh, dan budaya.

Ekspresi politik dalam tulisan ini merujuk pada pemahaman bahwa ekspresi politik merupakan kebebasan, bagian penting dari kebebasan ekspresi yang ditujukan sebagai sikap politik, menyatakan

19 Majelis Umum Perserikatan Bangsa-Bangsa menegaskannya dalam UN G.A. Res. 217 (III) A, Universal Declaration of Human Rights, art. 19 (Dec. $10,1948)$. 
atau mengkritisi kebijakan, pemangku wewenang, pembentuk hukum, atau kebebasan dalam memilih dan dipilih. Intinya, ekspresi yang ditujukan terhadap pemangku kepentingan publik atau penyelenggara kekuasaan.

Pernyataan politik, dalam konteks Papua, seperti menentukan nasib sendiri, merupakan pernyataan ekspresi politik yang terkait dengan kepentingan publik secara lebih luas. Hal demikian pula dilindungi dan dihormati, bahkan kritik terhadap kekuasaan atas sikap atau tindakan represifnya, berbagai bentuk ancaman, intimidasi, kekerasan, maupun diskriminasi terhadap pernyataan politik, harus dilarang dan wajib ditindak sesuai ketentuan hukum. ${ }^{20}$

Tentu, segala bentuk pernyataan politik dan ekspresinya yang mengandung siar kebencian, isu SARA, hasutan, dan memicu kekerasan maupun diskriminasi, adalah ekspresi yang dilarang, bisa dibatasi, ditindak menurut ketentuan hukum. Bagaimana dalam praktik penegakan hukum di Indonesia berkaitan dengan ekspresi politik? Dalam kasus Papua, ada dua isu yang kerap dituduhkan sebagai makar, yakni pertama, ekspresi yang menyuarakan penentuan nasib sendiri, biasanya dikaitkan dengan keinginan referendum. Kedua, ekspresi yang sifatnya simbolis, seperti mengusung simbol bintang kejora.

\section{Referendum}

Papua dan Papua Barat adalah wilayah paling banyak pelanggaran hak asasi manusianya di Indonesia. Pasukan keamanan Indonesia memerangi pemberontakan separatis, menangkapi banyak warga sebagai tahanan politik, namun hal itu tak menyurutkan dukungan untuk kemerdekaan. Diperlukan reformasi sektor keamanan yang kerap gunakan pendekatan kekerasan dan tidak dapat dipertanggungjawabkan sebagai bagian dari proses rekonsiliasi yang lebih luas dan kebutuhan mendesak akan kebijakan pembangunan yang berpusat pada warga Papua yang komprehensif. ${ }^{21}$ Faktanya, desakan

20 U.N. Human Rights Comm., General Comment No. 25 (57), U.N. Doc. CCPR/C/2 / Rev.1 / Add.7 (Aug 27, 1996).

21 Bobby Anderson, Papua's Insecurity: State Failure in the Indonesian Periphery 
referendum terus menguat, dan selalu direspons represif.

Ekspresi untuk menentukan nasib sendiri, atau self determination, sesungguhnya merupakan hak asasi manusia. Ia bagian dari ekspresi atau keyakinan politik, yang dilindungi dalam sistem hukum nasional maupun internasional (political expression is protected expression). Hal ini ditegaskan dalam Piagam Perserikatan Bangsa-Bangsa/PBB (1948) maupun secara khusus dalam Pasal 1 ICCPR. Pemerintah Indonesia memang mereservasi Pasal 1, sehingga tidak dibahas khusus. Sekalipun demikian, bukankah Indonesia mengakui Pasal 1 ayat 2 Piagam PBB, yang menyatakan "Untuk membangun hubungan baik antar bangsa-bangsa berbasis pada penghormatan prinsip hak-hak kesetaraan dan menentukan nasib sendiri dari rakyat, dan mengambil langkah-langkah layak untuk memperkuat perdamaian universal atau dunia."

Menariknya, dalam Pembukaan UUDNRI 1945 justru Indonesia telah menegaskan perlindungan dan jaminannya, dengan kalimat "Bahwa sesungguhnya kemerdekaan itu ialah hak segala bangsa dan oleh sebab itu, maka penjajahan di atas dunia harus dihapuskan, karena tidak sesuai dengan perikemanusiaan dan perikeadilan.”

Konstitusionalisme hak menentukan nasib sendiri, atau referendum, termasuk ajukan tuntutan supaya Pemerintah Indonesia melakukan referendum di Papua dan Papua Barat, justru merupakan ekspresi politik yang seharusnya diperbolehkan dalam kerangka hukum Indonesia. Apalagi, bahwa ekspresi melalui tuntutan referendum merupakan salah satu bentuk perubahan ketatanegaraan yang dikenal dan diakui dalam praktik penyelenggaraan ketatanegaraan di Indonesia, sekaligus menjadi sumber hukum ketatanegaraan. Dalam sejarahnya, referendum pernah dilakukan di Timor Timur pada 30 Agustus 1999 sebagai langkah Presiden RI B.J. Habibie, yang memberikan opsi bagi warga Timor Timur, apakah menerima otonomi khusus dalam NKRI atau menolak otonomi khusus yang menyebabkan pemisahan dari Indonesia.

Bahkan, bila diperhatikan dari sisi hukum pidana, sebagaimana 
dinyatakan dalam Pasal 110 ayat (4) KUHP, "Tidak dipidana barang siapa yang ternyata bermaksud hanya mempersiapkan atau memperlancar perubahan ketatanegaraan dalam artian umum." Artinya, ekspresi politik demikian jelas bukanlah suatu perbuatan makar, bahkan tidak bisa dipidana.

\section{Simbol Bintang Kejora}

Hal kedua yang pula kerap tersasar pasal makar adalah ekspresi politik dalam simbol-simbol, seperti penggunaan bendera, tato, tas ataupun medium apapun dengan 'bintang kejora'. Di masa Presiden Abdurahman Wahid (Gus Dur), ekspresi pengibaran bendera bintang kejora merupakan ekspresi yang dimaknai ekspresi sosial budaya. ${ }^{22}$ Sikap Gus Dur memang memantik perdebatan kontroversi. Hal ini karena bendera Bintang Kejora sudah dianggap lekat dengan simbol gerakan separatisme.

Koordinator Jaringan Gusdurian Indonesia, Alissa Wahid, mengatakan, Gus Dur memang memiliki pendekatan yang berbeda dalam merespons segala permasalahan di Papua, termasuk soal disintegrasi. Gus Dur, dengan pendekatan berbeda, tidak ingin adanya disintegrasi, dan ingin warga Papua merasa nyaman dalam mengekspresikan identitas kebudayaannya. Dengan begitu, diharapkan pula merasa nyaman dengan statusnya sebagai warga negara Indonesia. ${ }^{23}$

Pengibaran bendera bintang kejora sebagai ekspresi politik seharusnya dijamin, sejauh tanpa menggunakan upaya kekerasan, menghasut untuk melakukan kekerasan, sehingga sama sekali tidak ada alasan melarang dalam sistem hukum nasional. Sayangnya, kriminalisasi atau pemidanaan terhadap ekspresi politik dan protes

22 Tirto.id, "Sejarah Gus Dur yang Membolehkan Bintang Kejora Berkibar di Papua”, https://tirto.id/sejarah-gus-dur-yang-membolehkan-bintangkejora-berkibar-di-papua-ehpc, 2/9/2019, diakses 17/2/2021.

23 Kompas.com, "Apa Alasan Gus Dur Tidak Melarang Pengibaran Bendera Bintang Kejora?", https://nasional.kompas.com/ $\mathrm{read} / 2019$ / 09 / 04 / 15394551 / apa-alasan-gus-dur-tidak-melarangpengibaran-bendera-bintang-kejora?page=all., 4/9/2019, diakses 17 $/ 2 / 2021$. 
atas peristiwa rasisme justru bertentangan dengan prinsip-prinsip pembatasan yang diatur dalam Pasal 19 ICCPR.

Tiga alasan berbasis doktrin prinsip Siracusa untuk menyatakan bahwa pembatasan ekspresi politik itu bertentangan, yakni, pertama, ekspresi atau keyakinan politik, dan bahkan protes atas perlakuan diskriminasi rasial yang justru menjadi kewajiban setiap warga negara untuk menyuarakan atau melawannya. Kedua, pelarangan tidak sesuai dengan prinsip 'legitimated aim', atau alasan yang terlegitimasi dalam pasal 19 ayat (3) ICCPR. Pembatasan dengan pemidanaan harus memenuhi salah satu tujuan yang ditentukan yang tercantum dalam teks instrumen hukum hak asasi manusia. Ketiga, pemidanaan yang ditujukan atas ekspresi politik dan protes atas peristiwa rasisme, bertentangan dengan prinsip pembatasan 'necessary', karena menjadi tidak proporsional dengan tujuannya, dan bahkan sudah menjadi kewajiban negara untuk menjamin ekspresi politik maupun kewajiban negara untuk tidak diam atau membiarkan adanya peristiwa diskriminasi atau rasisme. Pemidanaan justru menghilangkan kebebasan dasar itu sendiri.

Penggunaan pasal makar, yaitu Pasal 106 KUHP dan 110 KUHP, tidaklah tepat, karena secara normatif simbol bintang kejora diatur secara khusus melalui Peraturan Pemerintah Nomor 77 Tahun 2007 tentang Lambang Daerah. Pasal 6 ayat (4) menyatakan, "Desain logo dan bendera daerah tidak boleh mempunyai persamaan pada pokoknya atau keseluruhannya dengan desain logo dan bendera organisasi terlarang atau organisasi/perkumpulan/lembaga/gerakan separatis dalam Negara Kesatuan Republik Indonesia”. Penjelasan pasal itu menyatakan,

Yang dimaksud dengan desain logo dan bendera organisasi terlarang atau organisasi/ perkumpulan/lembaga/gerakan separatis dalam ketentuan ini misalnya logo dan bendera bulan sabit yang digunakan oleh gerakan separatis di Provinsi Aceh, logo burung mambruk dan bintang kejora yang digunakan oleh gerakan separatis di Provinsi Papua, serta bendera benang raja yang digunakan oleh gerakan separatis di Provinsi Maluku.

Peraturan Pemerintah yang dibuat masa Presiden Soesilo Bambang Yudhoyono ini tentu secara hukum pula tidak tepat, karena 
bertentangan dengan standar hukum HAM berkaitan dengan ekspresi politik maupun ekspresi sosial budaya. Bahkan, bila dianalisis lebih mendalam, dari sudut pandang teori perundang-undangan, adalah tidak tepat pengaturannya.

Ada enam alasan mengapa Peraturan Pemerintah ini tidak sesuai dengan teori perundang-undangan. Pertama, kerangka pelarangan norma tidak boleh diatur dalam bagian penjelasan, karena penjelasan bukan norma baru atau perintah. ${ }^{24}$ Kedua, Penjelasan hanya untuk menjelaskan original intend (niat pembentuk hukum), dan hanya digunakan untuk membaca ketentuan tersebut, karena dimungkinkan bahwa lingkup penjelasan frasa ketentuan satu dengan ketentuan lainnya berbeda sesuai kebutuhan dari aturan tersebut. Ketiga, Penjelasan suatu ketentuan hukum karena bukan norma, tidak juga digunakan untuk mendikte hakim atau lembaga peradilan dalam memaknai pasal, karena pada dasarnya hakim memiliki kebebasan menggunakan interpretasi atau penafsiran apapun.

Alasan keempat, bahwa tradisi hukum negara lain, baik dalam sistem civil law maupun common law, undang-undangnya maupun peraturan pemerintahnya jarang disertai penjelasan (explanatory memoranda/elucidation), karena mereka merasa atau menganggap penjelasan itu 'breach to judicial power' (bertentangan dengan kekuasaaan kehakiman yang memiliki kebebasan menafsirkan). Kelima, dengan kekhususan merujuk simbol tertentu, maka secara teori perundang-undangan pun, bentuk hukum yang tepat untuk obyek larangan atau pembatasan bukanlah berdasarkan produk hukum regeling (pengaturan), melainkan produk hukum beschikking (keputusan).

Alasan keenam, bertentangan dengan ketentuan lebih tinggi. Bahwa Bab II Pasal 2 ayat (2) Undang-Undang Nomor 21 Tahun 2001 tentang Otonomi Khusus bagi Provinsi Papua, menyatakan, simbol kultural bagi kemegahan jati diri orang Papua dalam bentuk bendera

24 Bagus Hermanto, Nyoman Mas Aryani, dan Ni Luh Gede Astariyani, "Penegasan Kedudukan Penjelasan suatu Undang-Undang: Tafsir Putusan Mahkamah Konstitusi”, Jurnal Legislasi Indonesia, 17, 3 (2020), hlm. 251-68. 
daerah. ${ }^{25}$ Ketentuan ini kedudukannya lebih tinggi dibandingkan produk hukum Pasal 6 Pemerintah Nomor 77 Tahun 2007 tentang Lambang Daerah. Ini berarti, dengan asas hukum lex superior derogat legi inferior, justru seharusnya tidak boleh bertentangan dengan ketentuan hukum lebih tinggi.

Ringkasnya, kebebasan ekspresi politik yang kemudian dituduhkan makar, sesungguhnya tidak hanya bertentangan dengan prinsipprinsip pembatasan hak asasi manusia, atau kebebasan ekspresi, melainkan pula justru bertentangan dengan standar hukum normatif yang dimiliki dalam sistem hukum Indonesia itu sendiri.

\section{Makar dalam Putusan Mahkamah Konstitusi Nomor 7 / PUU-XV / 2017}

Dalam perkembangan hukum dan bekerjanya hukum soal makar, mengalami dinamika politik tersendiri. Di masa pemerintahan Presiden Jokowi, pernah memberikan grasi kepada lima tahanan politik yang dianggap kelompok separatis kelompok Organisasi Papua Merdeka (OPM), yang saat itu ditahan di Penjara Abepura, Jayapura, Papua. Mereka adalah Linus Hiluka dan Kimanus Henda (keduanya divonis 19 tahun 10 bulan), Numbungga Telenggen dan Jefrai Murib (keduanya divonis seumur hidup), serta Apotnalogolik Lokobalm (vonis 20 tahun). Berpidato di sebuah ruangan di lantai atas Lembaga Pemasyarakatan Abepura, Jayapura, Provinsi Papua, Presiden Joko Widodo mengatakan pemberian grasi tersebut merupakan upaya pemerintah dalam menyelesaikan konflik di Papua. ${ }^{26}$

Menariknya, dinamika tersebut pula diperkuat oleh putusan yang terbilang maju dan penting kedudukannya sebagai 'landmark decision'. Hal ini karena ratio decidendi Putusan Mahkamah Konstitusi Nomor 7/PUU-XV/2017 menegaskan telah ditemukan fakta Jaksa

25 "Provinsi Papua dapat memiliki lambang daerah sebagai panji kebesaran dan simbol kultural bagi kemegahan jati diri orang Papua dalam bentuk bendera daerah dan lagu daerah yang tidak diposisikan sebagai simbol kedaulatan."

26 BBC.com, "Presiden Jokowi beri grasi untuk lima tapol di Papua", https: / / www.bbc.com/indonesia / berita_indonesia/2015/05/150509_papua_ grasi_jokowi, 9/5/2015, diakses 8/5/2020. 
Penuntut Umum dan Hakim salah menerapkan unsur "makar", ${ }^{27}$ Makar hanya dimaknai sebagai unsur "niat", bukan "perbuatan" sebagaimana mestinya, sehingga dalam banyak putusan tersebut tidak ada pembuktian terkait perbuatan "makar" yang berarti "serangan" ("Aanslag"). ${ }^{28}$ Penegakan hukum demikian akibatkan banyak kerugian konstitusional hak warga negara.

Ada empat argumen dasar yang menjadi ratio decidendi putusan Mahkamah Konstitusi tersebut. Pertama, pemaknaan atau penafsiran frasa "makar" haruslah dimaknai "serangan" dengan maksud supaya seluruh atau sebagian wilayah negara jatuh ke tangan musuh atau memisahkan sebagian dan wilayah negara, diancam dengan pidana penjara seumur hidup atau pidana penjara. Ini artinya, tindak pidana makar adalah 'delik selesai' dan bukan merupakan tindak pidana percobaan. Dalam praktik penegakan hukum, tindak pidana makar dimaknai sebagai perbuatan tindak pidana percobaan. Kedua, putusan Mahkamah Konstitusi tersebut menegaskan hukuman berat tindak pidana makar adalah sebuah tindak pidana yang perlu ekstra kewaspadaan bagi pemerintah karena sangat berkaitan dengan kelangsungan kehidupan kenegaraan yang tujuan fundamentalnya adalah melindungi segenap rakyat.

Ketiga, putusan Mahkamah Konstitusi mengoreksi kesalahan penerapan dalam penegakan hukum, khususnya penegakan hukum yang menimbulkan ketidakpastian hukum karena penegak hukum baru dapat melakukan tindakan hukum terhadap seseorang yang diduga melakukan tindak pidana makar apabila orang yang bersangkutan telah melakukan tindakan "serangan" dan telah nyata timbul korban. Ini artinya, tidak cukup pembuktian sekadar

27 Frasa makar dalam Pasal 87, Pasal 104, Pasal 106, Pasal 107, Pasal 139a, Pasal 139b, dan Pasal 140 Undang-Undang Nomor 1 Tahun 1946.

28 "Aanslag" (makar atau penyerangan) itu biasanya dilakukan dengan perbuatan kekerasan”. Bahwa kemudian perbuatan makar (aanslag) ditujukan tergantung pada tujuan yang tercantum pada pasal, misalnya Pasal 104 yaitu melakukan "penyerangan dengan perbuatan kekerasan dengan niat hendak membunuh aanranding (penyerangan dengan maksud tidak baik) atau merampas kemerdekaan atau menjadikan tidak cakap memerintah Presiden atau Wakil Presiden. Vide: R. Soesilo, KUHP Serta Komentar-komentarnya: Lengkap pasal demi Pasal (Bogor: Politea, 1996). 
unsur "niat", sementara unsur "perbuatan" pula harus dibuktikan. ${ }^{29}$ Keempat, putusan Mahkamah Konstitusi menegaskan bahwa penegak hukum harus berhati-hati dalam menerapkan pasal-pasal yang berkenaan dengan makar sehingga tidak menjadi alat untuk membungkam kebebasan menyampaikan pendapat dalam negara demokratis yang menjadi salah satu semangat UUD $1945 .{ }^{30}$

Berbasis ratio decidendi demikian, maka pemidanaan atas ekspresi dengan pengibaran bendera bintang kejora sebagai bentuk protes atau ekspresi atas peristiwa rasisme di Surabaya, adalah tidak hanya tidak tepat secara hukum, melainkan pula bertentangan dengan doktrin hukum hak asasi manusia dan justru bertolak belakang dengan bagaimana yang dimaknakan dalam Putusan Mahkamah Konstitusi Nomor 7/PUU-XV/2017.

\section{E. Makar dan Doktrin Hukumnya}

Konsekuensi Pemerintah Indonesia meratifikasi ICCPR adalah pula tunduk pada sistem hukum PBB berkaitan dengan pelaksanaan hak-hak sipil dan politik. ${ }^{31}$ Pelaksanaan tersebut berkaitan dengan bagaimana menafsirkan suatu hak atau kebebasan, pembatasanpembatasan atas hak dan kebebasan tersebut, sekaligus panduan atas prinsip-prinsipnya, tak terkecuali dalam soal kebebasan ekspresi. ${ }^{32}$

29 Putusan Mahkamah Konstitusi Nomor 7/PUU-XV/2017, hlm. 155.

30 Putusan Mahkamah Konstitusi Nomor 7/PUU-XV/2017, hlm. 157.

31 Indonesia menjadi State Party dari ICCPR pada 23 Februari 2006, setelah disahkannya UU No. 12 Tahun 2005 tentang Pengesahan International Covenant on Civil and Political Rights (ICCPR). Badan pengawas dari ICCPR adalah Komite HAM (Human Rights Committee) yang memiliki mandat dan kewenangan mengawasi dan mensupervisi implementasi ICCPR di setiap Negara Pihak, serta mengeluarkan tafsir otoritatif untuk memperbaharui dan memkontekstualisasi ketentuan-ketentuan dalam ICCPR untuk bisa menyesuaikan diri dengan perkembangan jaman.

32 Kebebasan ekspresi, termasuk ekspresi politik dalam instrumen hukum HAM Internasional, diatur dalam Pasal 19 ayat 3 ICCPR, dan penafsiran atas 'pembatasan yang diijinkan' dikembangkan melalui sejumlah doktrin hukum, antara lain, (1) Siracusa Principles on the Limitation and Derogation Provisions in the International Covenant on Civil and Political Rights (1984); (2) Rule of law in a state of emergency: the Paris minimum standards of human rights norms in a state of emergency (International Law Association's Committee, 
Institusi seperti Komite HAM, prosedur khusus dan ahli PBB, pula Kelompok Kerja Penahanan Sewenang-wenang (UNWGAD) ${ }^{33}$, akan memungkinkan untuk terus memberikan pengawasan, atau kerja berbasis mandat yang dimilikinya. Banyaknya warga Papua yang ditahan atas tuduhan makar memperlihatkan sistematiknya perampasan kebebasan sewenang-wenang, dari tahun ke tahun, waktu ke waktu. UNWGAD menyatakan istilah "perampasan kebebasan sewenang-wenang" (arbitrary deprivation of liberty) ${ }^{34}$ mencakup semua bentuk penahanan secara fisik yang membatasi kebebasan untuk berpindah tempat/bergerak di luar kesukarelaan orang bersangkutan (baik bersifat sah maupun tidak sah/sewenangwenang), termasuk mereka yang ditahan atau dipenjara karena suatu masalah hukum, mereka yang ditempatkan di institusi psikiatrik, penahanan administratif bagi para pencari suaka (asylum seeker) atau tempat detensi imigrasi, tahanan rumah, tempat penahanan anak, tempat penahanan di airport atau pelabuhan, dan sebagainya. Pelanggaran HAM terjadi bila "perampasan kebebasannya" bersifat sewenang-wenang atau tidak sah. Pentingnya jaminan untuk tidak terjadinya "perampasan kemerdekaan secara sewenang-wenang", sehingga ketentuan ini tidak diperkenankan diderogasi (dikurangi) bahkan di masa perang atau kondisi darurat lainnya, dan UNWGAD telah menyatakan bahwa larangan "perampasan kemerdekaan secara sewenang-wenang” merupakan suatu norma prinsipil hukum

1984); (3) Johannesburg Principles on National Security, Freedom of Expression and Access to Information (November 1996); (4) Camden Principles on Freedom of Expression and Equality (2009).

33 UN Working Group on Arbitrary Detention (UNWGAD), informasi khusus lembaga inibisa disimak di https:/ / www.ohchr.org/EN/Issues/Detention/ Pages/WGADIndex.aspx atau https://www.ohchr.org/Documents/ Issues/Detention/FactSheet26.pdf., diakses 15/3/2020.

34 UN Human Rights Committee General Comment No. 35 on Article 9 Liberty and security of person (ICCPR), UN Doc. 16 Desember 2014, para 5 dan 66, UN Doc. CCPR/C/GC/35.; UN Human Rights Council, Report of the Working Group on Arbitrary Detention, 24 Desember 2012, UN Doc. A/HRC/22/44, para 52 - 60 dan 75, bisa diakses di: https://www.ohchr.org/Documents/ HRBodies/HRCouncil/RegularSession/Session22/A.HRC.22.44_en.pdf, diakses 15/2/2020. Lihat: Papang Hidayat, Pidana Makar dan Hukum HAM International, makalah untuk Amnesty Internasional, 2020. 
internasional yang tidak bisa dikurangi (jus cogens atau a peremptory norm of international law).

Selain itu, perampasan kebebasan ini terkait pula dengan hak atas keamanan pribadi (liberty and security of person). Untuk memahami perampasan kebebasan tersebut, UNWGAD menyusun lima kategori yang menjadi doktrin dalam sistem hukum PBB. ${ }^{35}$ UNWGAD membuat lima kategori arbitrary deprivation of liberty tersebut. ${ }^{36}$ Kategori tersebut dinyatakan pula oleh Komite HAM melalui penafsiran doktrin otoritatif dalam sistem hukum HAM, khususnya melalui Komentar Umum. ${ }^{37}$

Lima kategori tersebut secara ringkas sebagai berikut. Kategori pertama, ketika jelas tidak ada dasar hukum apa pun yang membenarkan perampasan kebebasan, seperti ketika seseorang ditahan dalam penahanan setelah masa hukumannya selesai atau meskipun ada ketentuan hukum (amnesti) yang berlaku untuknya (membebaskan dirinya). Penting untuk dicatat bahwa penahan atau perampasan kemerdekaan yang sah menurut hukum domestik (nasional) bisa dianggap bersifat sewenang-wenang menurut perspektif HAM jika ketentuan domestik tersebut tidak sesuai dengan standar HAM internasional, seperti bila ketentuan hukum nasional tersebut bersifat kabur, luas, atau bertentangan dengan ketentuan substantif hak-hak asasi lainnya. ${ }^{38}$

Kategori kedua, ketika perampasan kebebasan terjadi dari pelaksanaan hak atau kebebasan dijamin oleh Pasal 7, 13, 14, 18, 19, 20, dan 21 dari Deklarasi Universal Hak Asasi Manusia (DUHAM) ${ }^{39}$ dan,

35 UN Human Rights Council, Methods of Work of the Working Group on Arbitrary Detention, 13/7/2017, UN Doc. A/HRC/36/38, paragraf (para) 8.

36 UN, Methods of Work of the Working Group on Arbitrary Detention, para 8.

37 UN Human Rights Committee General Comment No. 35 on Article 9 Liberty and security of person (ICCPR), UN Doc. 16 Desember 2014, para 10-23.

38 Amnesty International, Fair Trial Manual, Second Edition, 9 April 2014, Index: POL 30/002/2014, hlm. 33, https://www.amnesty.org/en/documents/ POL30/002/2014/en/, diakses 15/2/2020.

39 Pasal 7 (kesetaraan dan non-diskriminasi di muka hukum), Pasal 13 (kebebasan untuk bepergian di dalam dan ke luar negeri), Pasal 14 (hak untuk mencari suaka), Pasal 18 (hak untuk berkeyakinan, memiliki nurani, 
sejauh yang terkait dengan Negara-negara Pihak, oleh Pasal 12, 18, 19, 21, 22, 25, 26, dan 27 dari ICCPR. ${ }^{40}$ Kasus-kasus termasuk dalam kategori ini adalah ketika penahanan digunakan sebagai respons terhadap pelaksanaan yang sah hak-hak asasi, seperti menangkap aksi damai hanya untuk menjalankan hak mereka atas kebebasan berpendapat dan berekspresi, kebebasan berkumpul secara damai dan berserikat, atau menahan para pengungsi karena menggunakan hak mereka untuk mencari suaka dan/atau kebebasan untuk meninggalkan negara mereka sendiri.

Kategori ketiga, ketika kepatuhan (total atau sebagian) terhadap norma-norma internasional yang berkaitan dengan hak atas peradilan yang adil (right to a fair trial), ditetapkan dalam DUHAM dan dalam instrumen hukum internasional yang relevan dan diterima oleh negara-negara yang bersangkutan, dilanggar secara serius sehingga terjadi perampasan kebebasan secara sewenang-wenang. Untuk mengevaluasi karakter sewenang-wenang atau kasus-kasus perampasan kebebasan di bawah kategori ini, UNWGAD akan mempertimbangkan, di samping prinsip-prinsip (right to a fair trial) umum yang ditetapkan dalam DUHAM, beberapa prinsip fair trial yang diambil dari Badan Prinsip-Prinsip untuk Perlindungan Semua Orang di Bawah Segala Bentuk Penahanan atau Penjara ${ }^{41}$ dan, bagi negara-negara pihak pada ICCPR, kriteria yang ditetapkan khususnya

dan beragama), Pasal 19 (hak atas kebebasan berpendapat dan berekspresi), Pasal 20 (hak untuk berkumpul secara damai dan berasosiasi), dan Pasal 21 (hak untuk berpartisipasi dalam urusan pemerintahan dan kepentingan publik) DUHAM.

40 Pasal 12 (kebebasan untuk bepergian di dalam dan ke luar negeri), Pasal 18 (hak untuk berkeyakinan, memiliki nurani, dan beragama), Pasal 19 (hak atas kebebasan berpendapat dan berekspresi), Pasal 21 (hak untuk berkumpul secara damai dan berasosiasi), Pasal 22 (hak untuk berorganisasi dan membentuk serikat pekerja), Pasal 25 (hak untuk berpartisipasi dalam urusan pemerintahan dan kepentingan publik), Pasal 26 (kesetaraan dan non-diskriminasi di muka hukum), dan Pasal 27 (hak-hak kaum minoritas atas kebudayaan, Bahasa, dan agamanya) ICCPR.

41 Body of Principles for the Protection of All Persons under Any Form of Detention or Imprisonment, diadopsi Resolusi Majelis Umum PBB 43/173, 9/12/1988. https://www.ohchr.org/EN/ProfessionalInterest/Pages/ DetentionOrImprisonment.aspx, diakses 15/3/2020. 
diatur dalam Pasal 9 dan $14 .^{42}$

Kategori keempat, ketika para pencari suaka, imigran, atau pengungsi dikenakan tahanan administratif yang berkepanjangan tanpa kemungkinan peninjauan hukum atau administratif, atau pemulihan hak. Dan, kategori kelima, ketika perampasan kebebasan merupakan pelanggaran hukum internasional karena alasan diskriminasi berdasarkan kelahiran, asal kebangsaan/kewarganegaraan, etnis, atau asal sosial, bahasa, agama, kondisi ekonomi, opini politik atau lainnya, jender, orientasi seksual, atau disabilitas atau status lainnya, dan yang bertujuan atau dapat mengakibatkan terabaikannya kesetaraan HAM.

Bagaimana doktrin lima kategori tersebut digunakan praktik, khususnya dalam merespons kasus-kasus tudingan makar di Papua? Dari kelima kategori tersebut, meskipun dominan dalam uraian artikel ini ke kategori kedua dan ketiga, sesungguhnya seluruh kategori tersebut sistematik dilanggar dan tidak pernah menjadi acuan perubahan atas situasi penanganan kasus dan penegakan hukumnya. Penerapan pidana makar terhadap para aktivis politik Papua justru mempertegas pelanggaran hak asasi manusia sebagaimana disebutkan dalam kategori-kategori di atas. ${ }^{43}$

Dalam kunjungan resmi ke Indonesia, UNWGAD membuat catatan laporan termasuk memberikan pendapat bagi para pihak. Sebagai contoh, kunjungan yang merespons peristiwa Biak Berdarah (1998). Pengibaran bendera bintang kejora di Biak, Papua 2-6 Juli 1998 yang berujung pada penembakan secara membabi buta ratusan pengunjuk rasa dan juga kriminalisasi terhadap beberapa aktivis politik Papua lewat Pasal $106 \mathrm{KUHP},{ }^{44} \mathrm{UNWGAD}$ menyatakan bahwa

42 ICCPR Pasal 9 (hak atas kebebasan dan keamanan pribadi) dan pasal 14 (hak atas peradilan yang adil).

43 Herlambang P. Wiratraman, "Jaminan Perlindungan Kebebasan Ekspresi dalam Sistem Hukum HAM”, keterangan ahli dalam perkara pidana kasus makar/tapol Papau dengan terdakwa Buchtar Tabuni, Agus Kossay, Ferry Kombo, Stevanus Itlay, Hengki Hilapok, dan Alexander Gobai, Pengadilan Negara Balikpapan, 2020.

44 UN Human Rights Commission, Report of the Working Group on Arbitrary Detention on its visit to Indonesia, 31/1-12/2/1999), para 64-65. 
penahanan (pemenjaraan) atau perampasan kemerdekaan mereka bersifat sewenang-wenang karena mereka melakukan aktivitas politik berdasarkan pandangan dan keyakinan politik mereka secara damai (yang merupakan hak asasi manusia fundamental dan dilindungi oleh hukum HAM internasional) dan masuk dalam kategori kedua terkait perampasan kemerdekaan sewenang-wenang yang dibuat oleh UNWGAD. ${ }^{45}$ Begitu juga kasus pemidanaan terhadap Filep Jacob Semuel Karma, aktivis pro-kemerdekaan Papua, yang divonis bersalah dan dipenjara 15 tahun karena melakukan makar (Pasal 106 dan 110 KUHP) ketika berpartisipasi dalam upacara damai peringatan deklarasi kemerdekaan Papua di Abepura, Jayapura, Provinsi Papua pada 1 Desember 2004. Berdasarkan Opinion No. 48/2011, tertanggal 2 September 2011, memperlihatkan pula pelanggaran HAM atas kategori kedua dan ketiga. ${ }^{46}$ Filep, keluar masuk penjara berulang kali karena tuduhan makar, terakhir bebas pada November 2015.

Argumen jaksa maupun majelis hakim yang memutus perkara dominan menggunakan perspektif adanya ancaman keamanan negara (nasional) sebagai dasar untuk menyatakan penerapan pasal makar. ${ }^{47}$ Perspektif demikian dominan karena narasi sejarah integrasi dari pemerintah Indonesia itu sendiri, yang tentu masih menyisakan perdebatan faktual. ${ }^{48}$ Berkaitan dengan perspektif keamanan nasional

45 UN, Report of the Working Group on Arbitrary Detention, para 60, 62, dan 65.

46 UNWGAD, Opinion No. 48/2011 (Indonesia), 2/9/2011, UN Doc. A/HRC/ WGAD/2011/48, dapat diakses pada https://documents-dds-ny.un.org/ doc/UNDOC / GEN/G12 / 115 / 90 / PDF / G1211590.pdf?OpenElement., diakses $15 / 3 / 2020$.

47 PN Jakarta Pusat dengan nomor register No. 1303/Pid.B/2019/PN Jkt. Pst. Paulus Suryanta Ginting, Charles Kosay, Ambrosius Mulait, dan Isay Wenda didakwa karena melakukan makar sebagaimana dimaksud dalam Pasal 106 KUHP jo. Pasal 55 ayat (1) ke-1 KUHP atau Pasal 110 KUHP.; Putusan PN Balikpapan Nomor 35 /Pid.B/2020/PN.BPP, terdakwa Fery Kombo, yang didakwa pasal 106 KUHP. Selain Fery Kombo, dakwaan yang sama diputus di PN Balikpapan, yakni Sejumlah enam tahanan politik lain yang juga diadili di Pengadilan Negeri Balikpapan adalah Hengky Hilapok, Buchtar Tabuni, Irwanus Uropmabin, Stevanus Itlay alias Steven Itlay, dan Agus Kossay.

48 Eileen Hanrahan, West Papuan Decolonisation (Singapore: Palgrave Macmillan, 2021). 
tersebut, sesungguhnya dalam doktrin hukum HAM telah disediakan panduan para ahli hukum sebagai sumber hukum yang digunakan dalam mengukur sejauh mana tindakan negara dibolehkan maupun dibatasi dalam rangka menghadapi kasus-kasus serangan atau makar, yakni Prinsip-Prinsip Johannesburg (The Johannesburg Principles on National Security, Freedom of Expression and Access to Information, Freedom of Expression and Access to Information). ${ }^{49}$

Prinsip Johannesburg menyatakan ekspresi yang bukan merupakan ancaman terhadap keamanan nasional adalah ekspresi untuk mengadvokasi perubahan kebijakan negara atau bentuk negara itu sendiri yang dilakukan tanpa kekerasan; ekspresi yang merupakan suatu kritik, hinaan, atau ejekan kepada suatu bangsa, negara atau simbol-simbol negara, pemerintah (dan organ-organnya), pejabat publik, bangsa asing, negara atau simbol-simbol negara asing, pemerintah asing, atau pejabat publik negara asing; dan atau, mengkomunikasikan atau menyebarkan informasi-informasi tentang dugaan pelanggaran HAM. Ekspresi demikian disebut sebagai "manifestasi suatu pendapat yang dilindungi (protected expression)" dan melarang keras negara untuk memenjarakan bagi mereka yang melakukannya. ${ }^{50}$

Bila dibandingkan dengan konstruksi KUHP di Indonesia, Prinsip Johannesburg pula menegaskan prasyarat dan pembuktian apa yang dimaknai dengan 'mengancam keamanan nasional', yakni ekspresi yang diniatkan sengaja untuk menghasut kekerasan yang dalam waktu dekat akan terjadi; ekspresi yang kemungkinan besar akan memicu kekerasan; dan ada hubungan langsung dan segera antara suatu ekspresi dan kemungkinan atau terjadinya kekerasan. ${ }^{51}$

Dalam kasus Surya Anta, dkk. di Pengadilan Negeri Jakarta Pusat maupun Fery Kombo, dkk. di Pengadilan Negeri Balikpapan, pemidanaannya hanya didasari pada soal kepemilikan, penyebaran,

49 The Johannesburg Principles on National Security, "Freedom of Expression and Access to Information”, https://www.article19.org/wp-content/ uploads / 2018/02/joburg-principles.pdf., 1/10/1995, diakses 2/1/2020.

50 The Johannesburg Principles, Principle 7. Prinsip ini pula disebutkan dalam UN Human Rights Committee General Comment No. 34, para 38.

51 The Johannesburg Principles, Principle 6. 
pengibaran, atau pembentangan bendera atau simbol terlarang (Bendera Bintang Kejora untuk Papua), yang diasosiasikan penegak hukum sebagai simbol separatis atau pro-kemerdekaan, adalah tidak tepat penerapannya dalam doktrin Prinsip Johannesburg tersebut. Bendera atau simbol-simbol yang 'terlarang' tersebut jelas tidak melambangkan atau bisa diinterpretasikan sebagai bentuk 'ajakan melakukan kekerasan'.

Sayangnya, dalam putusan di Pengadilan Negeri Jakarta Pusat maupun Pengadilan Negeri Balikpapan, sama sekali tidak mempertimbangan perkembangan Putusan Mahkamah Konstitusi maupun doktrin hukum kebebasan ekspresi dan hak asasi manusia, termasuk Prinsip Johannesburg ini. Secara terbatas, berbeda dengan Pengadilan Negeri Jakarta Pusat dan Pengadilan Negeri Balikpapan, putusan Majelis Hakim di Pengadilan Negeri Jayapura tidak menggunakan pasal makar untuk memidana Assa Asso. Putusan Pengadilan Negeri Jayapura menyatakan Assa Asso tidak terbukti melakukan makar, dengan mempertimbangkan ratio decidendi Putusan Mahkamah Konstitusi. Majelis hakim menyatakan Assa Asso hanya dinyatakan bersalah melakukan penghasutan sebagaimana diatur Pasal 160 KUHP, dan menjatuhkan hukuman 10 bulan penjara dipotong masa penahanan.

Putusan Assa Asso, sekalipun telah dibebaskan dari tuduhan makar, namun tetap saja ia dihukum pidana karena tuduhan penghasutan karena mengunggah foto di media sosial. Dalam konteks ini, bila proses peradilan terus menerus melakukan represi atau penghukuman atas dasar stigma makar, maka proses hukum yang berjalan sangat dipengaruhi oleh cara pandang rasisme dan diskriminasi, dan tentunya menghilangkan hak atau kebebasannya mengekspresikan sikap untuk menyampaikan pesan terkait hak asasi manusia. ${ }^{52}$ Proses hukum dan peradilan demikian terlekati politik

52 Majelis Hakim seharusnya mempertimbangkan UN General Comment No. 34: Article 19: Freedoms of opinion and expression (Human Rights Committee,102nd session, Geneva, 11-29 July 2011). Paragraf 3 secara tegas menyatakan, "bahwa pelaksanaan hak kebebasan berekspresi disertai dengan tugas dan tanggung jawab khusus. Untuk alasan ini ada wilayah secara terbatas kaitannya dengan pembatasan hak yang diizinkan dalam 
penegakan hukum yang cenderung rasis dan terinstitusionalisasi, atau institutionalised racism, dan politiknya menjadi melekat dalam upaya mendiskriminasi secara rasial, atau embedded racism politics. Hal demikian terlihat dari penegakan hukum yang senantiasa diskriminatif terhadap warga Papua, utamanya dengan tuduhan berulang kali makar atas kebebasan ekspresi politiknya. ${ }^{53}$

Indonesia telah meratifikasi International Convention on the Elimination of All Forms of Racial Discrimination (ICERD 1965) menjadi Undang-Undang No 29 Tahun 1999 tentang Pengesahan ICERD (Konvensi Internasional tentang Penghapusan Segala Bentuk Diskriminasi Rasial). Selain itu, berkaitan dengan materi sama untuk mencegah sikap anti rasisme, Indonesia pula mengesahkan UndangUndang Nomor 40 Tahun 2008 tentang Penghapusan Diskriminasi Ras dan Etnik. Sekalipun demikian, situasi tidak banyak berubah. Masalahnya, sejauh mana realitas institutionalised racism dalam penegakan hukum dapat dihentikan melalui mekanisme hukum yang ada?

Frasa dalam ratio decidendi Putusan Mahkamah Konstitusi Nomor 7/PUU-XV/2017 soal makar, yakni "Aparat penegak hukum harus berhati-hati dalam menerapkan pasal-pasal makar sehingga tidak jadi alat membungkam kebebasan menyampaikan pendapat dalam negara demokratis yang menjadi semangat UUD 1945”, merupakan frasa yang harus diupayakan koherensi argumenargumen hukum di lapangan, baik aparat penegak hukum di

rangka untuk menghormati hak atau nama baik orang lain atau untuk perlindungan keamanan nasional atau ketertiban umum (public order), atau kesehatan atau moral publik. Namun, ketika pihak Negara melakukan pembatasan maka pelaksanaan kebebasan berekspresi, tidak dibolehkan justru membuat hilangnya hak itu sendiri". Komite mengingatkan "bahwa hubungan antara hak dan pembatasan dan antara norma dan pengecualian tidak boleh menyebabkan situasi berbalik."

53 Herlambang P. Wiratraman, "Kebebasan Ekspresi dan Makar dalam Sistem Hukum HAM”, keterangan ahli dalam persidangan Perkara No. 1303/ Pid.B/2019/PN.Jkt.Pst; dan Perkara No. 1305/Pid.B/2019/PN.Jkt.Pst, di PN Jakarta Pusat, atas nama terdakwa Paulus Suryanta Ginting Charles Kossay, Dono Tabuni, Issay Wenda Ambrosius Mulait dan Arina Elopere, $3 / 4 / 2020$. 
kepolisian, kejaksaan, maupun di lingkungan kekuasaan kehakiman. Sekaligus tantangannya, diperlukan keberanian dan integritas dalam menegakkan hukum tanpa sikap diskriminatif rasial terhadap warga Papua.

Tidak digunakannya argumen Mahkamah Konstitusi dalam ratio decidendinya, mengakibatkan putusan-putusan majelis hakim dilevel pengadilan negeri terkesan tidak peduli perkembangan hukum itu. Wawancara dengan pengacara, kerap menyesalkan argumen jaksa maupun hakim yang tidak menggunakan nalar hukum dan terkesan memaksakan hal-hal yang tidak dilakukan terdakwa dalam kasus makar. Dalam suatu wawancara, salah seorang pengacara, $\mathrm{K}$ (anonim), yang mendampingi terdakwa kasus makar Papua, menyebutkan, “... faktanya seperti itu, pledoi kita pikir mereka 'taruh di tempat sampah', alur jaksa dalam tuntutan yang mereka (hakim) ikuti, .... sebagus apapun materi pembelaan kita dengan referensi dari berbagai sumber dan fakta yang valid, hakim tidak membacanya, bahkan mungkin dia taruh di tempat sampah. Pertimbangan yang lazim dalam putusan hanya satu paragraf, 'tidak sependapat dengan nota pembelaan penasehat hukum'..." 54

Wawancara ini merefleksikan pikiran penegak hukum abai atas prosedur dan substansi hukum, dan menggampangkan masalah hukum yang kerap disederhanakan sebagai masalah makar. Sekalipun demikian, latar belakangnya lebih disebabkan cara pandang rasisme terhadap warga Papua, yang menghukum warga Papua tanpa landasan hukum yang kuat.

\section{F. Kesimpulan}

Penerapan frasa makar dalam penegakan hukumnya, terutama dalam merespons kasus ekspresi politik warga Papua, memperlihatkan jauh dari standar hukum dan hak asasi manusia, baik dalam kerangka normatif, koherensi dalam memahami konsekuensi putusan peradilan, hingga tiadanya pemanfaatan argumen doktrin kebebasan ekspresi yang sudah banyak diatur dan maju. Sejumlah putusan

54 Wawancara, K, pengacara, 25/4/2021. 
pengadilan negeri, terutama dalam studi ini di Pengadilan Negeri Jakarta Pusat, Balikpapan, dan Jayapura, atas puluhan mahasiswa dan warga Papua yang dipidana, memperlihatkan sistem hukum yang menjamin kebebasan ekspresi politik tidak banyak berubah dan penegakan hukum justru menegaskan posisi diskriminasi rasial serta jauh dari standar hukum dan doktrin hak asasi manusia. Tuduhan makar yang dalam proses hukumnya dicari-cari kesalahannya yang sebenarnya tidak mampu dibuktikan di peradilan namun tetap dihukum justru cerminan watak rasis penegakan hukumnya.

Memang, argumen dalam putusan pengadilan yang tidak sesuai standar hukum dan hak asasi manusia, atau bahkan pengabaian putusan Mahkamah Konstitusi, tidak serta merta atau seketika bisa dikatakan rasis dan diskriminatif. Masalahnya, bila dalam praktik putusan majelis demikian terus menerus terjadi, berulang, disadari secara institusional mengabaikannya tanpa memperdebatkan putusan Mahkamah Konstitusi, dan sama sekali tidak mempertimbangkan argumen hukum yang telah diingatkan Mahkamah Konstitusi dalam putusannya, bahkan terus menerus mengorbankan warga Papua atau mereka yang bersolidaritas terhadap warga Papua yang dilanggar kebebasan ekspresi politiknya, maka level penerapan dan penegakan hukum demikian justru perlihatkan karakter represif. Karakter penegakan hukum represif dilatari oleh pandangan yang diskriminatif dan kuat motivasi rasismenya. Hal ini terhubung dengan pendekatan keamanan yang terus menerus mendominasi cara pandang kekuasaan atas upaya penyelesaian kasus Papua, bukan dengan dialog apalagi penuntasan kasus-kasus impunitas atas pelanggaran hak-hak asasi manusia. Tekanan terhadap ekspresi politik Papua ini memperlihatkan keterhubungan kasus-kasusnya dengan aksi anti rasisme Surabaya, namun suara atau ekspresi politik tersebut justru dibungkam dengan pemidanaan.

Meskipun, secara khusus, pertimbangan putusan yang berkualitas, terutama pemanfaatan ratio decidendi Putusan Mahkamah Konstitusi Nomor 7/PUU-XV/2017 yang menyatakan telah ditemukan fakta jaksa penuntut umum dan hakim salah menerapkan unsur "makar", seharusnya menjadi pembelajaran maju dalam 
penegakan hukumnya. Kekeliruan penegak hukum selama ini karena makar hanya dimaknai sebagai unsur "niat", bukan "perbuatan" sebagaimana mestinya, sehingga dalam banyak putusan tersebut tidak ada pembuktian terkait perbuatan "makar" yang berarti "serangan" (anslaag). Penegakan hukum demikian akibatkan banyak kerugian konstitusional hak warga negara, terus menerus, berulang tanpa ada sistem koreksi yang memperlihatkan komitmen politik hukum pemerintah maupun di internal kekuasaan kehakiman.

Upaya mengkriminalkan atau memenjarakan mahasiswa dan warga Papua atas aksi menolak rasisme lebih dipengaruhi oleh kepentingan politik kekuasaan daripada pertimbangan hukum, sehingga karakter penegakan hukum lebih mencerminkan realitas diskriminasi rasial dan bahkan level represif, yang sayangnya kian terinstitusionalisasi (institutionalised racism). 'Kasus makar' memperlihatkan lemah atau tiadanya komitmen dalam menjalankan mandat baik Indonesia sebagai negara pihak pada ICCPR maupun mandat konstitusional Pasal 28I ayat (4) UUDNRI, bahwa "perlindungan, pemajuan, penegakan, dan pemenuhan hak asasi manusia adalah tanggung jawab negara, terutama pemerintah".

\section{Daftar Pustaka}

\section{Artikel, Buku, dan Laporan}

Amnesty International. Fair Trial Manual, Second Edition. London: Amnesty International, 2014. https://www.amnesty.org/ en/documents/POL30/002/2014/en/, 9/4/2014. Diakses $15 / 2 / 2020$.

Anderson, Bobby. Papua's Insecurity: State Failure in the Indonesian Periphery. Singapore: ISEAS, 2015.

BBC.com. "Presiden Jokowi Beri Grasi untuk Lima Tapol di Papua”. https://www.bbc.com/indonesia/berita_indonesia/2015/05/150509_papua_grasi_jokowi, 9/5/2015. Diakses $8 / 5 / 2020$.

CNNIndonesia.com. "Asrama Papua di Surabaya Dilempari Karung Berisi Ular Piton”. https://www.cnnindonesia. 
com/nasional/20190909102739-20-428670/asrama-papua-disurabaya-dilempari-karung-berisi-ular-piton, 9/9/2019. Diakses $15 / 2 / 2021$.

CNNIndonesia.com. "Polisi Tetapkan 20 Tersangka Kasus Makar di Papua”. https://www.cnnindonesia.com/nasional/20191202205913-12-453521/polisi-tetapkan-20-tersangkakasus-makar-di-papua, 2/12/2019. Diakses 16/2/2021.

Goodyear-Ka'ōpua, Noelani dan April K. Henderson. Morning Star Rising: The Politics of Decolonization in West Papua. Hawaii: University of Hawaii Press, 2021.

Gunawan, dkk. Papua on Trial: Uraian Penjelasan Perhimpunan Bantuan Hukum dan Hak Asasi Manusia Indonesia atas Pengadilan HAM perkara Abepura dan Pelanggaran HAM di Papua. Jakarta: Perhimpunan Bantuan Hukum dan Hak Asasi Manusia Indonesia, 2005.

Hanrahan, Eileen. West Papuan Decolonisation. Singapore: Palgrave Macmillan, 2021.

Hermanto, Bagus, Nyoman Mas Aryani, dan Ni Luh Gede Astariyani.

"Penegasan Kedudukan Penjelasan suatu Undang-Undang: Tafsir Putusan Mahkamah Konstitusi”. Jurnal Legislasi Indonesia, 17, 3 (2020): 251-68.

Hidayat, Papang. "Pidana Makar dan Hukum HAM International". Makalah untuk Amnesty Internasional, 2020.

International Law Association's Committee. Rule of law in a State of Emergency: the Paris Minimum Standards of Human Rights Norms in a State of Emergency, 1984.

Johannesburg Principles on National Security. "Freedom of Expression and Access to Information". https://www.article19.org/wpcontent/uploads/2018/02/joburg-principles.pdf., 1/10/1995. Diakses 2/1/2020

Kirksey, Eben. Freedom in Entangled Worlds: West Papua and the Architecture of Global Power. Durham London: Duke University Press, 2012.

Kompas.com. "Apa Alasan Gus Dur Tidak Melarang Pengibaran Bendera Bintang Kejora?”. https://nasional.kompas.com/ 
$\mathrm{read} / 2019 / 09 / 04 / 15394551$ / apa-alasan-gus-dur-tidak-melarang-pengibaran-bendera-bintang-kejora?page=all., 4/9/2019. Diakses 17 /2/2021.

Panjaitan, Lani Sujiagnes, Alvi Syahrin, Marlina, dan Jelly Leviza.

"Penerapan Hukum Pidana terhadap Tindak Pidana Makar oleh Organisasi Papua Merdeka (OPM) di Kabupaten Jayawijaya (Studi Putusan Nomor 38/Pid.B/2011/PN.Wmn)". USU Law Journal, 4, 3 (2016): 88-98.

Soesilo, R. KUHP serta Komentar-komentarnya: Lengkap Pasal Demi Pasal. Bogor: Politea, 1996.

Siracusa Principles on the Limitation and Derogation Provisions in the International Covenant on Civil and Political Rights (1984).

The Camden Principles on Freedom of Expressionand Equality (2009).

Tirto.id. "Timpangnya Putusan Hukum Pelaku dan Pemrotes

Rasisme ke Orang Papua”. https://tirto.id/timpangnyaputusan-hukum-pelaku-dan-pemrotes-rasisme-ke-orangpapua-fF6j, 9/6/2020. Diakses 15/2/2021.

Tirto.id. "Siklus Rasisme terhadap Mahasiswa Papua”. https:// tirto.id/ siklus-rasisme-terhadap-mahasiswa-papua-egA4, 20/8/2019. Diakses 16/2/2021.

Tirto.id. "Sejarah Gus Dur yang Membolehkan Bintang Kejora Berkibar di Papua”. https://tirto.id/sejarah-gus-dur-yangmembolehkan-bintang-kejora-berkibar-di-papua-ehpc, 2/9/2019. Diakses 17/2/2021.

Widjojo, Muridan Satrio, Adriana Elisabeth, dan Amirudin Al Rahab. Papua Road Map: Negotiating the Past, Improving the Present, and Securing the Future. Jakarta: LIPI, 2010.

Wijayanto, dkk. Nestapa Demokrasi di Masa Pandemi: Refleksi 2020, Outlook 2021. Jakarta: LP3ES, 2021.

Wiratraman, Herlambang P. "Hak-Hak Konstitusional Warga Negara setelah Amandemen UUD 1945: Konsep, Pengaturan dan Dinamika Implementasi.” Jurnal Hukum Panta Rei, 1, 1 (2007): 1-19.

Wiratraman, Herlambang P. "Jaminan Perlindungan Kebebasan 
Ekspresi dalam Sistem Hukum HAM”. Keterangan ahli dalam perkara pidana kasus makar/tapol Papua, terdakwa Buchtar Tabuni, Agus Kossay, Ferry Kombo, Stevanus Itlay, Hengki Hilapok, dan Alexander Gobai, Pengadilan Negara Balikpapan, 2020.

Wiratraman, Herlambang P. "Kebebasan Berekspresi: Penelusuran Pemikiran dalam Konsitusi Indonesia”. Jurnal Konstitusi, 6, 1 (2009): 105-34.

Wulandari, Widati dan Tristam P. Moeliono. "Problematika Pengertian Aanslaag-Aanslaag tot en Feit: Perbandingan Makar dalam KUHP, WvSNI dan SR". Padjadjaran Jurnal Ilmu Hukum, 4, 3 (2017): 473-92. DOI: 10.22304/pjih.v4n3.a3.

\section{Peraturan dan Putusan Hukum}

Republik Indonesia, Mahkamah Konstitusi. Putusan Nomor $7 /$ PUU-XV/2017, tanggal 31/1/2018, perkara Pengujian Undangundang Nomor 1 Tahun 1946 tentang Peraturan Hukum Pidana (Kitab Undang-Undang Hukum Pidana) terhadap UndangUndang Dasar Negara Republik Indonesia Tahun 1945.

Republik Indonesia, Pengadilan Negeri Balikpapan. Putusan Nomor Nomor 35 / Pid.B/2020/PN.BPP, tanggal 17/6/2020, perkara tindak pidana makar dengan terdakwa Fery Kombo.

Republik Indonesia, Pengadilan Negeri Jakarta Pusat. Putusan Nomor Nomor 1303/Pid.B/2019/PN Jkt.Pst., 24/4/2020, perkara tindak pidana makar dengan terdakwa Paulus Suryanta Ginting, Charles Kosay, Ambrosius Mulait, dan Isay Wenda.

United Nations, General Assembly Resolution 217 (III) A. Universal Declaration of Human Rights, 10/12/1948.

United Nations, Human Rights Committe. General Comment No. 25 (57), U.N. Doc. CCPR/C/2/Rev.1/Add.7, 27 / 8/1996.

United Nations. General Comment No. 34: Article 19: Freedoms of Opinion and Expression (Human Rights Committee, 102nd session, Geneva, 11-29 July 2011)

United Nations, Working Group on Arbitrary Detention(UNWGAD). https: / / www.ohchr.org/EN/Issues/Detention/Pages / 
WGADIndex.aspx;https://www.ohchr.org/Documents / Issues / Detention/FactSheet26.pdf. Diakses 15/3/2020.

United Nations, Working Group on Arbitrary Detention(UNWGAD). Opinion No. 48/2011 (Indonesia), 2/9/2011, UN Doc. A/HRC/ WGAD/2011/48, bisa diakses di: https:// documents-dds-ny. un.org/ doc/UNDOC/GEN/G12/115/90/PDF/G1211590. pdf?OpenElement. Diakses 15/3/2020.

United Nations, Human Rights Committee General Comment No. 35 on Article 9 Liberty and security of person (ICCPR), UN Doc. 16 Desember 2014, para 5 dan 66, UN Doc. CCPR/C/GC/35. United Nations, Human Rights Council. Report of the Working Group on Arbitrary Detention, 24 Desember 2012, UN Doc. A/HRC/22/44, para 52-60 dan 75. https://www.ohchr. org / Documents / HRBodies / HRCouncil / RegularSession / Session22/A.HRC.22.44_en.pdf.

United Nations, Human Rights Council. Methods of Work of the Working Group on Arbitrary Detention, 13 Juli 2017, UN Doc. A/HRC/36/38, paragraf (para) 8 .

United Nations, GA Resolution. Body of Principles for the Protection of All Persons under Any Form of Detention or Imprisonment, 43/173, 9/12/1988.https://www.ohchr.org/ EN/ProfessionalInterest/Pages / DetentionOrImprisonment. aspx. Diakses 15/3/2020.

United Nations, Human Rights Commission. Report of the Working Group on Arbitrary Detention on its visit to Indonesia (31/112/2/1999), para 64-65. 